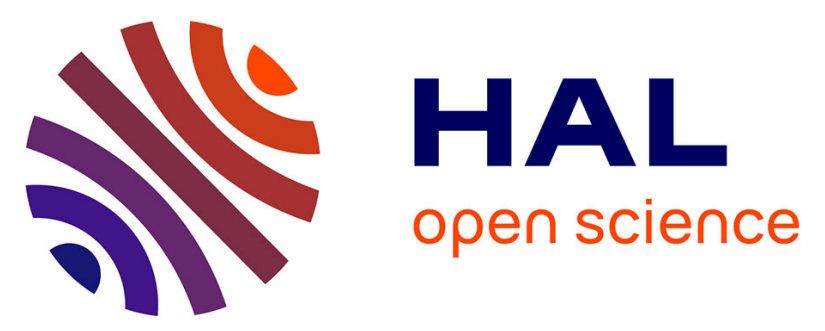

\title{
Bayesian inversion of a chloride profile obtained in the hydraulically undisturbed Opalinus Clay: mass transport and paleo-hydrological implications.
}

Catherine Yu, Julio Goncalves, Jean-Michel Matray

\section{- To cite this version:}

Catherine Yu, Julio Goncalves, Jean-Michel Matray. Bayesian inversion of a chloride profile obtained in the hydraulically undisturbed Opalinus Clay: mass transport and paleo-hydrological implications.. Applied Geochemistry, 2018, 93, pp.178-189. 10.1016/j.apgeochem.2017.11.004 . hal-01771469

\author{
HAL Id: hal-01771469 \\ https://hal.science/hal-01771469
}

Submitted on 27 Jan 2020

HAL is a multi-disciplinary open access archive for the deposit and dissemination of scientific research documents, whether they are published or not. The documents may come from teaching and research institutions in France or abroad, or from public or private research centers.
L'archive ouverte pluridisciplinaire HAL, est destinée au dépôt et à la diffusion de documents scientifiques de niveau recherche, publiés ou non, émanant des établissements d'enseignement et de recherche français ou étrangers, des laboratoires publics ou privés.

\section{(1) (1) $\$$}

Distributed under a Creative Commons Attribution - NonCommercial - NoDerivatives 44.0 
Manuscript Number:

Title: Bayesian inversion of a chloride profile obtained in the hydraulically undisturbed opalinus Clay: mass transport and paleohydrological implications

Article Type: Research Paper

Keywords: Mont Terri rock laboratory, opalinus Clay, natural tracer profile, chloride, Markov Chain Monte Carlo, leaching, diffusion

Corresponding Author: Mrs. Catherine Yu,

Corresponding Author's Institution: IRSN

First Author: Catherine Yu

Order of Authors: Catherine Yu; Julio Gonçalvès, Pr.; Jean-Michel Matray, Dr.

Abstract: The BDB-1 deep-inclined borehole was drilled at the Mont Terri rock laboratory (Switzerland) and enabled to acquire relevant data on porewater composition through the opalinus clay (OPA) and its bounding formations. Petrophysical measurements were carried out and included water content, water accessible porosity and grain density determination. Mobile anion profiles were obtained by aqueous leaching and out diffusion experiments performed on drillcore samples, and revealed to be consistent with previous studies carried out at the rock laboratory level. Diffusive properties were also investigated using three experimental setups: parallelepiped out diffusion, radial diffusion and through diffusion. These transport parameters were used as a priori values in a Monte Carlo Markov Chain inversion modelling approach to interpret the chloride profile in the opalinus Clay. Based on a Peclet number analysis, a purely diffusive scenario enabled specifying the paleohydrogeological evolution of the Mont Terri site from the folding of the Jura Mountains and transport parameters.

Suggested Reviewers: Claude Degueldre Pr. Professor of Nuclear Engineering, Engineering, Lancaster University c.degueldredancaster.ac.uk

Margarita Koroleva Dr. Geol.-Pal. Institute, Universität Hamburg margarita.korolevaduni-hamburg.de

Ana Maria Fernandez Dr. Departamento de Medio Ambiente, CIEMAT anamaria.fernandez@ciemat.es

Andreas Gautschi

Chief Geoscientific Advisor, Advisory Team Science \& Technology, NAGRA Andreas. Gautschi@nagra.ch 
Paul Wersin Dr.

Institut fuir Geologie, University of Bern

paul. wersinggeo.unibe.ch 


\section{Title of the submitted manuscript:}

Bayesian inversion of a chloride profile obtained in the hydraulically undisturbed Opalinus Clay: mass transport and paleo-hydrological implications

\section{List of all authors' names and affiliations:}

Catherine $\mathrm{Yu}^{1)}{ }^{2)}$, Julio Gonçalvès ${ }^{2)}$, Jean-Michel Matray1)

1) Institut de Radioprotection et de Sûreté Nucléaire, 31 Allée du Général Leclerc, F92260 Fontenay-aux-Roses, France

2) Aix Marseille Univ., CNRS, IRD, Coll. De France, CEREGE, Aix-en-Provence, France

Short statement of the precise problem or objective addressed in the paper: $(<50$ words $)$

Understanding the salinity profile and its transient geological evolution across the Opalinus Clay at Mont Terri as a prerequisite for further transient interpretation of pressure profile.

\section{Brief description of the essence of the approach :( $<100$ words $)$}

The paper presents an exhaustive and self-consistent acquisition of transport parameters and natural tracer profiles in the hydraulically undisturbed zone crossed by the BDB-1 borehole, which is the first deep borehole drilled at the Mont Terri rock laboratory. The obtained chloride profile was interpreted by means of a purely diffusive 1D numerical model, based on a statistical approach enabling to obtain fitted parameters and associated confidence intervals.

\section{List of the specific major novel contributions reported here :up to 3}

- Consistency between data acquired at the Mont Terri tunnel level and in the hydraulically undisturbed zone crossed by the BDB-1 deep borehole.

- Confirmation of the paleohydrogeological evolution of the Mont Terri site from the folding of the Jura Mountains.

List of other journal or conference papers published or submitted that have a significant overlap with the contribution sumitted here accompanied by a brief explanation of the nature of this overlap pointing ou clearly which novel ideas submitted here have not been discussed in these prior publications: 
- Acquisition of anion profiles and diffusion coefficients in the Opalinus Clay at the Mont Terri rock laboratory (Switzerland), Yu, C, Matray, J.M., 2017, Procedia Earth and Planetary Science, Vol. 17, Pages 57-60. Published

- Characterisation of anions and stable water isotopes diffusive properties in the Opalinus Clay by three experimental setups applied on BDB-1 borehole samples, C. Yu, C., Matray, J.-M., Bagagnan, S., Wittebroodt, C., Michelot, J.-L., 2017. $7^{\text {th }}$ International Conference on Clays in Natural and Engineered Barriers for Radioactive Waste Confinement. Submitted and accepted for poster presentation.

These papers focused essentially on the experimental part of our work and did not detail our transport modelling at geological formation scale.

\section{A reference to the closest prior article (by others) upon which your contributions improve:}

Mazurek, M., Alt-Epping, P., Bath, A., Gimmi, T., Waber, H.N., Buschaert, S., De Cannière, P., De Craen, M., Gautschi, A., Savoye, S., Vinsot, A., Wemaere, I., Wouters, L., 2011. Natural tracer profiles across argillaceous formations. Appl. Geochem., 26, 1035-1064

\section{Names, emails, and homepage URLs of four experts covering these areas and fields:}

- Claude Degueldre, c.degueldre@lancaster.ac.uk, http://www.lancaster.ac.uk/engineering/about-us/people/claude-degueldre

- Margarita Koroleva, margarita.koroleva@uni-hamburg.de, http://4dweb.proclim.ch/4dcgi/polar/en/Detail Person?korolevam.bern

- Jim Hendry, jim.hendry@usask.ca, http://artsandscience.usask.ca/profile/MHendry\#/profile

- Martin Mazurek, martin.mazurek@geo.unibe.ch http://4dweb.proclim.ch/4dcgi/geosciences/en/Detail Person?mazurekm.bern

Names of the two GMOD associate editors who we believed are the most qualified to handle our paper:

Philippe Negrel and Elisa Sacchi

\section{Technical areas and fields of expertise necessary to fully understand our contribution and to evaluate its potential and novelty:}

Hydrogeology, transport modelling 
1 Bayesian inversion of a chloride profile obtained in the hydraulically undisturbed

2 Opalinus Clay: mass transport and paleo-hydrological implications

3 Catherine $\mathrm{Yu}^{1)}{ }^{2)}$, Julio Gonçalvès ${ }^{2)}$, Jean-Michel Matray ${ }^{1)}$

4 1) Institut de Radioprotection et de Sûreté Nucléaire, 31 Allée du Général Leclerc, 5 F92260 Fontenay-aux-Roses, France

2) Aix Marseille Univ., CNRS, IRD, Coll. De France, CEREGE, Aix-en-Provence, 7 France

8 Corresponding author: Catherine Yu. E-mail: catherine.jiyu@irsn.fr

9 Keywords: Mont Terri rock laboratory, Opalinus Clay, natural tracer profile, chloride, 10 Markov Chain Monte Carlo, leaching, diffusion 


\section{Abstract}

13 The BDB-1 deep-inclined borehole was drilled at the Mont Terri rock laboratory 14 (Switzerland) and enabled to acquire relevant data on porewater composition through the 15 Opalinus Clay (OPA) and its bounding formations. Petrophysical measurements were carried 16 out and included water content, water accessible porosity and grain density determination.

17 Mobile anion profiles were obtained by aqueous leaching and out diffusion experiments 18 performed on drillcore samples, and revealed to be consistent with previous studies carried 19 out at the rock laboratory level. Diffusive properties were also investigated using three 20 experimental setups: parallelepiped out diffusion, radial diffusion and through diffusion. 21 These transport parameters were used as a priori values in a Monte Carlo Markov Chain 22 inversion modelling approach to interpret the chloride profile in the Opalinus Clay. Based on 23 a Peclet number analysis, a purely diffusive scenario enabled specifying the 24 paleohydrogeological evolution of the Mont Terri site from the folding of the Jura Mountains 25 and transport parameters. 


\section{Introduction}

The Swiss National Co-operative for the Disposal of Radioactive Waste (Nagra) selected the Opalinus Clay (OPA) as a potential host rock suitable for deep geological repository of highlevel radioactive waste and long-lived-intermediate-level waste. The evaluation of the confinement properties of this formation has been ongoing since 1996 in the Mont Terri rock laboratory, which is located in the Jura Mountains in north-western Switzerland. An overview of the safety aspects covered by this international research program and its contribution to the understanding of argillaceous formation behaviour was given by Bossart et al. (2017).

Solute transport is considered to be dominated by diffusion in compacted claystones due to their low permeability (Patriarche et al., 2004b; Sellin and Leupin, 2014). Limited water flow in these formations make standard sampling of porewater non applicable. Unconventional extraction processes based on physical or chemical extraction were developed and include centrifugation, squeezing, leaching, advective displacement and diffusive equilibration (Sachi et al., 2001). Natural tracer profiles across argillaceous formations give information on fluid flow and transport properties, as they result from a long-term exchange between the aquitard and the bounding aquifers porewaters (Mazurek et al., 2011; Bensenouci et al., 2013). The example of the Opalinus Clay was studied through the interpretation of several natural tracers $\left(\mathrm{Cl}^{-}, \delta^{2} \mathrm{H}\right.$ and $\left.\mathrm{He}\right)$ profiles by Mazurek et al. (2011). This study concluded that a purely diffusive transport model could explain the present profiles and proposed values for activation times of the Opalinus Clay bounding aquifers and initial chlorinity. However, the mainly diffusive mass transport behavior was tested by means of a sensitivity test on advection using plausible but not based on global driving forces (pressure, temperature, salinity gradients) Darcy's velocity values and no corresponding Peclet number calculation were made. In addition, only a single value of the diffusion coefficient was applied to the stratigraphic column and no uncertainties were associated with the fitting parameters. 
51 At the end of 2014 and in the framework of the Deep Borehole experiment (DB), a $247.5 \mathrm{~m}$ 52 long $45^{\circ}$ downward inclined borehole named BDB-1 was drilled through the Opalinus Clay 53 and the bounding formations. The aim of the experiment is to develop and validate a 54 methodology for assessing the confinement properties of a thick argillaceous unit using the 55 Opalinus Clay as an example. In this framework, mobile anion profiles were acquired by 56 leaching and out diffusion experiments and diffusive transport parameters (effective diffusion 57 coefficients and accessible porosities) were also identified by radial and through diffusion 58 experimental setups.

59 This paper presents an exhaustive and self-consistent acquisition of transport parameters and 60 natural tracer profiles in the hydraulically undisturbed zone crossed by the BDB-1 borehole. 61 The chloride profile was interpreted by means of a purely diffusive $1 \mathrm{D}$ numerical model. The 62 assumption of purely diffusive mass transport phenomena was verified by estimating the 63 Peclet number including osmotic processes in the advection term. A bayesian inversion based 64 on effective diffusion coefficients, initial value of the chloride concentration and two 65 exhumation and thus hydraulic activation times for the two bounding aquifers (10 parameters) 66 allowed to evaluate the best fit parameter sets and their uncertainties not evaluated so far. 67 Obtaining a relevant interpretation of the chloride profile is crucial for water flow and flow 68 characterisation. Hence, overpressures (pore pressure exceeding the hydrostatic or 69 surrounding aquifer ones) were recognised in the Opalinus Clay and assumed so far to be 70 remnant from its burial history (Mazurek et al., 2002). The influence of osmotic phenomena 71 (water flow due to salinity or temperature gradients) on this pressure anomaly has not been 72 investigated yet and depends strongly on the porewater composition. Therefore, 73 understanding the salinity profile and its transient geological evolution across the formation is 74 a necessary prerequisite for further transient interpretation of pressure profile (Gonçalvès et 75 al., 2004). 


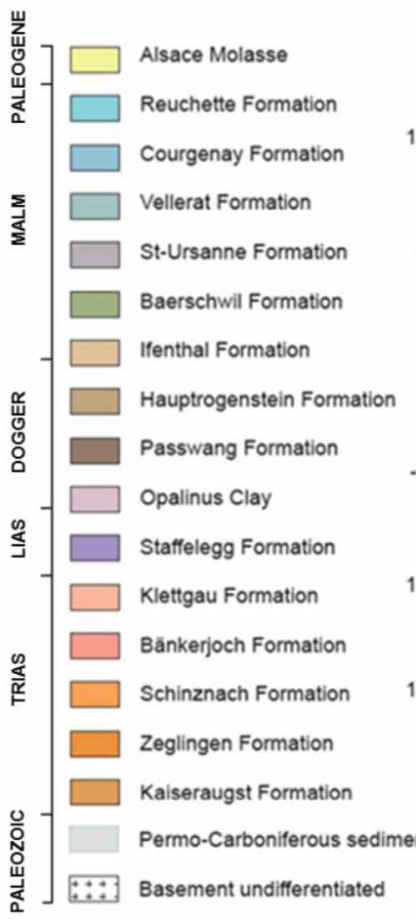
$90^{\circ} \mathrm{C}$ (Mazurek et al. 2006).

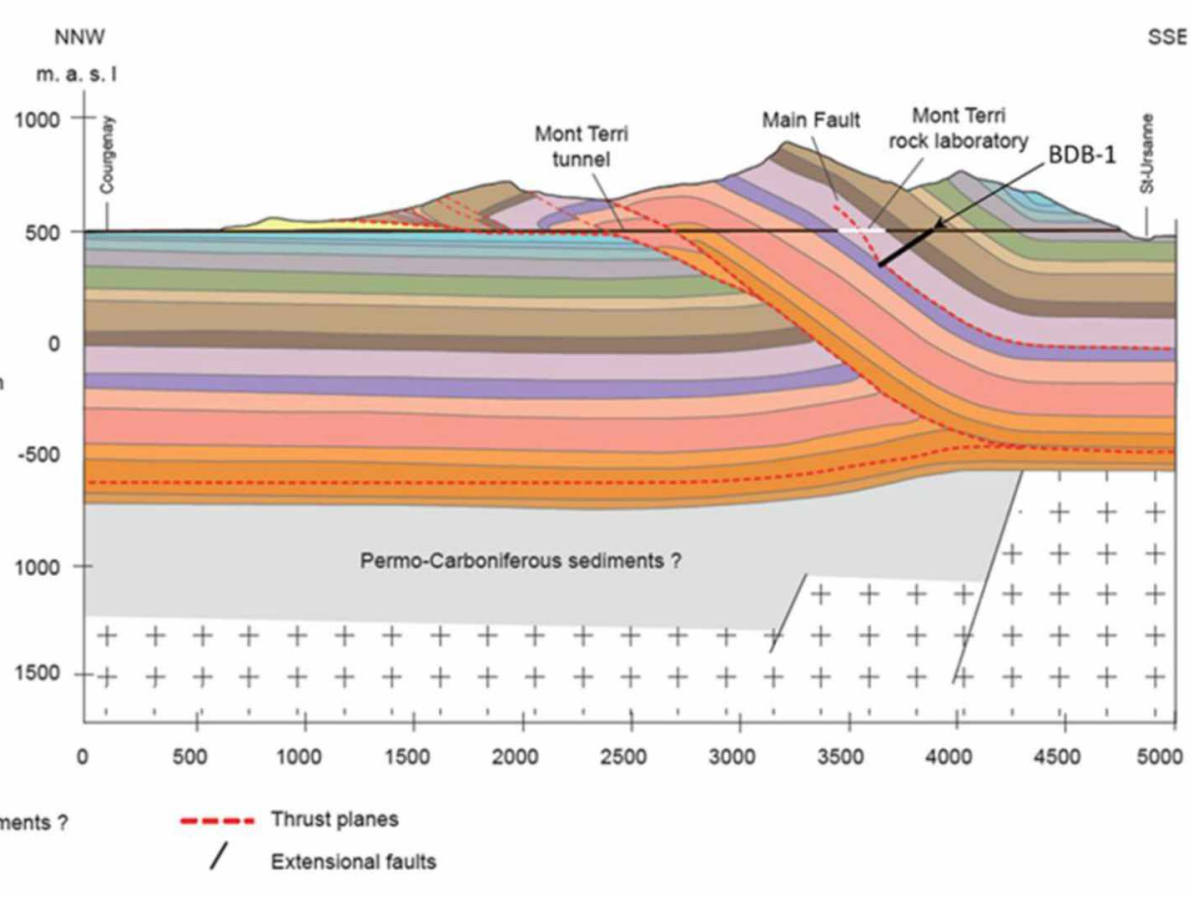

Figure 1: Geological cross-section of the Mont Terri anticline. Location of the rock laboratory is indicated by a white line. The BDB- 1 deep borehole, represented by a thick black line, crosses the lower part of the Dogger aquifer, the entire Opalinus Clay formation and the upper part of the Liassic marls (adapted from Nussbaum et al., 2017).

The Opalinus Clay at the Mont Terri site is an overconsolidated claystone of AalenianToarcian age, overlain by $800 \mathrm{~m}$ of Middle to Late Jurassic limestones, marls and shales, and underlain by $400 \mathrm{~m}$ of Early Jurassic to Triassic marls and limestones, dolomites and anhydrites (Figure 1). The thickness of the Opalinus Clay in the Mont Terri anticline varies between $130 \mathrm{~m}$ in the BDB-1 borehole and $160 \mathrm{~m}$ at rock laboratory level, depending on the tectonic contribution. This corresponds to a sedimentary thickness of about $120 \mathrm{~m}$, when corrected for tectonic overthrusting. The Opalinus Clay reached a burial depth of $1350 \mathrm{~m}$ about 120 Ma ago during early Cretaceous, which resulted in a maximum temperature of 80- 
91 A period of marine regression occurred between 100 and $40 \mathrm{Ma}$, leading to a subaerial 92 exposure of the top of the Malm limestone. Starting about $40 \mathrm{Ma}$, the rifting of the Rhine 93 Graben affected Northern Switzerland, resulting in considerable subsidence of the area in the mid-Tertiary, which brought the Opalinus Clay sequence back to about $500 \mathrm{~m}$ depth. According to Clauer et al. (2017), two sea invasions into the Mont Terri area took place during Priabonian (37 to $34 \mathrm{Ma}$ ) and during the Rupelian (34 to $28 \mathrm{Ma}$ ). Mazurek et al. (2017) proposed that the Malm limestones, represented by the Baershwil Formation, acted as a fresh-water boundary that induced a decrease of the Opalinus Clay porewater salinity to half the original value at the end of the Paleogene (23 Ma). Partial evaporation potentially occurred in the Chattian/Aquitanian and afterwards, brines would have diffused in the underlying formation, resulting in a salinity increase in the Opalinus Clay before Late Alpine folding during the late Miocene to Pliocene (about 12 to $3 \mathrm{Ma}$ ) that formed the Folded Jura. Erosion exposed the core of the Mont Terri anticline between 6 and $2.5 \mathrm{Ma}$, and activated the Middle Jurassic limestones aquifer (overlying the Opalinus Clay), causing a porewater flushing. Similarly, infiltration to the Early Jurassic limestones would have started in the Quaternary, between 0.5 and 0.2 Ma ago (Pearson et al., 2003, Mazurek et al., 2011).

107 Three main facies were identified within the Opalinus Clay (Blaesi et al., 1991): a shaly facies 108 in the lower part of the sequence, a thin carbonate-rich sandy facies in the middle part of the 109 formation, and a sandy facies interstratified with shaly facies in the upper sequence. The shaly 110 facies mineral composition includes $27-78 \%$ of clay minerals (illite, chlorite, kaolinite and 111 illite-smectite mixed layers), 4-29\% of carbonates, 10-32\% of quartz, and accessory feldspars, 112 pyrite and organic matter (Bossart and Thury, 2008).

113 Several minor tectonic faults and a larger fault zone called "Main Fault" can be observed in 114 the Opalinus Clay (Nussbaum et al., 2011). Nagra's investigations in deep boreholes at 115 Riniken, Weiach, Schafisheim and Benken revealed that the tectonically disturbed zones are 
116 hydraulically similar to the undeformed matrix (Johns et al. 1994; Gautschi 2001a). This 211 conclusion was also confirmed by hydraulic investigation in the BDB-1 borehole at Mont 4 118 Terri (Yu et al., 2017).

1193 Material and methods

$120 \quad 3.1$ Sampling

121 The stratigraphic sequence crossed by the BDB-1 borehole is presented in Figure 2 and is 122 described in detail in Hostettler et al. (2017). The Opalinus Clay section was drilled with air 123 as drilling fluid. Drilling was immediately followed by the installation of a multipacker 124 system (Fierz and Rösli, 2014) with pressure and temperature sensors. The borehole was 125 entirely cored for lithostratigraphic, petrophysical, mineralogical and geochemical studies. 126 Cores sent for analysis were sampled every $10 \mathrm{~m}$ along the borehole. Their preservation was 127 ensured by nitrogen flushing and sealing after vacuum with plastic foil in aluminum coated 128 plastic bags, in order to avoid further evaporation and contact with the atmosphere. 


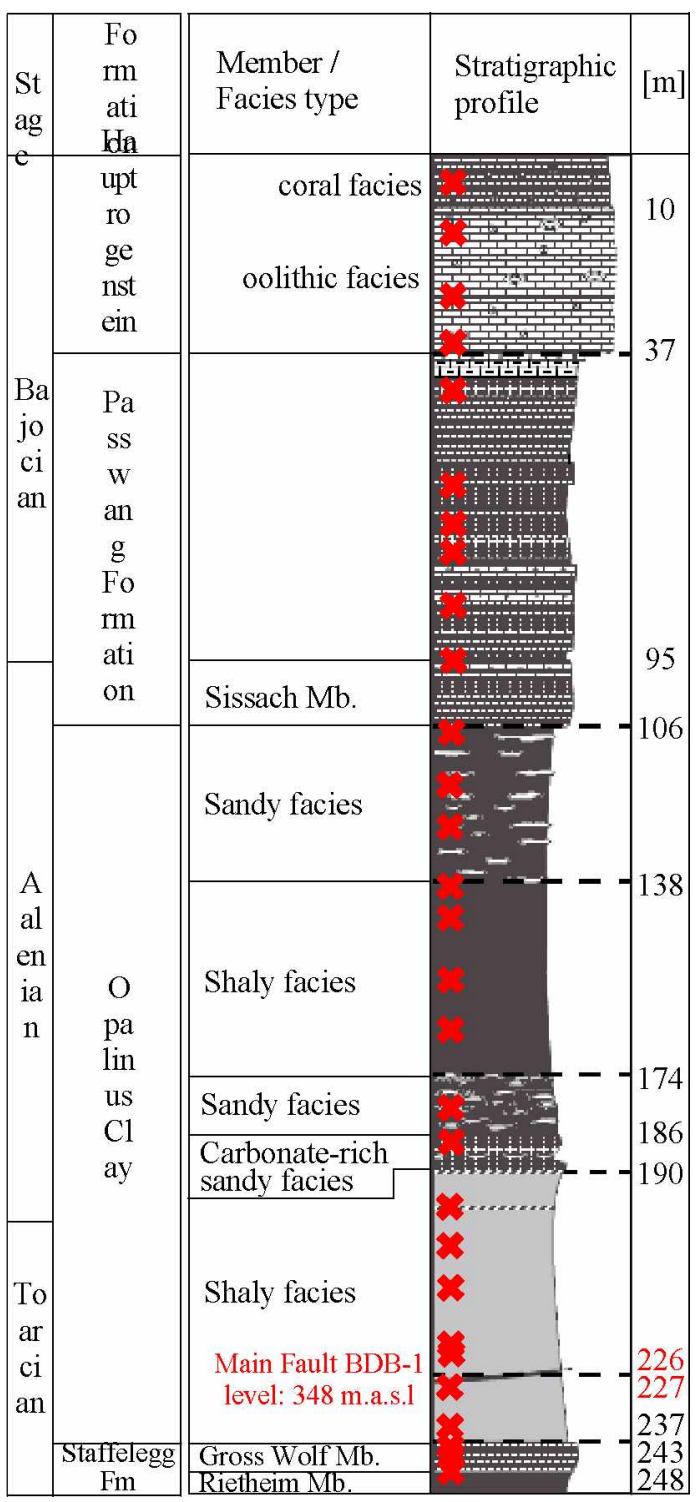

130 Figure 2: Lithostratigraphy of the formations crossed by BDB-1 borehole (adapted from 131 Hostettler et al., 2017) and approximative location of the studied samples represented by red 132 crosses.

133 3.2 Petrophysical characterisation

134 Determination of petrophysical parameters (water contents, porosity, apparent density, degree 135 of saturation etc.) were performed in laboratory on representative elementary volume samples 136 taken from the central part of the cores. Water contents were determined by weighing before 137 and after oven-drying at $105{ }^{\circ} \mathrm{C}$ until mass stabilization. Density and degree of saturation 138 were calculated based on Archimede's principle after sample immersion into kerdane (de- 
139 aromatized hydrocarbide), following the experimental protocol first proposed by Monnier et 140 al. (1973) and adapted to Tournemire and Mont Terri argillites (Matray et al., 2007; Matray and Möri, 2010). Grain density was evaluated using a helium pycnometer (Micromeritics 142 Accupyc II 1340) on oven-dried samples.

\section{$143 \quad 3.3$ Aqueous leaching}

144 Leaching consists in diluting pore water solutes contained in a powdered rock sample into a 145 leaching solution (Sachi et al. 2001, Koroleva et al. 2011). Samples were crushed, sieved ( $<$ $146100 \mu \mathrm{m})$ and placed together with deionised water at solid/liquid ratio of 1:2 in centrifuge 147 vessels. The procedure took place under controlled atmospheric condition in a glove box $\left(\mathrm{N}_{2}\right.$ 148 atmosphere). Centrifuge tubes were placed in a hermetic glass jar and stirred out of the glove 149 box using an end-over-end agitator during 2 hours. Then, samples were centrifuged at 10,000 $150 \mathrm{rpm}$ for 15 minutes and placed again inside the glovebox to be filtered with $0.22 \mu \mathrm{m}$ syringe 151 filter. Leachates were analysed by liquid ion chromatography using a Metrohm 861 Advanced

\subsection{Diffusion experiments}

154 Schematic views of the alternative experimental setups used to characterise the Opalinus Clay 155 are shown in Figure 3.
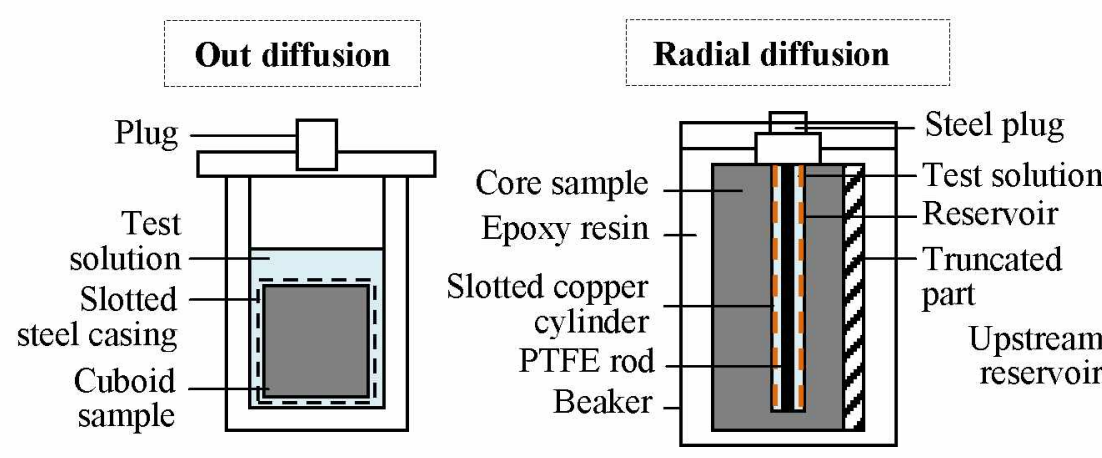
157 Figure 3: Schematic views of the diffusion cells used in this study to characterise the Opalinus 158 Clay diffusive properties

159 3.4.1 In and out-diffusion

160 In parallelepiped configuration, an out diffusion experiment consists in immersing a cubic161 shaped sample into a synthetic solution and sampling the solution until reaching diffusive 162 equilibrium. The method has been employed on argillite from Tournemire rock laboratory 163 (France) by Patriarche (2004a) and enables the estimation of halide concentrations in 164 porewater, as well as pore diffusion coefficient of the tested samples. Eighteen samples 165 measuring about $5 \mathrm{~cm}$ wide were prepared with a diamond wire saw. They were constrained 166 by placing a metallic grid, after being coated with epoxy resin on four faces to impose a single 167 diffusion direction (perpendicular or parallel to the bedding). Test solutions were prepared to 168 present a similar ionic strength to the porewater one, based on chloride contents obtained by 169 leaching experiments.

170 A radial diffusion experiment consists in diffusive equilibrium between pore water contained 171 in a drillcore and a test solution with known composition placed in an axial drilled reservoir 172 (Van der Kamp et al. 1996, Savoye et al. 2006a and 2006b). A total of ten samples were 173 prepared, each consisting of a core portion cut with a circular saw with a diameter of $10.2 \mathrm{~cm}$ 174 or $8.5 \mathrm{~cm}$ and a length between 6.7 and $10 \mathrm{~cm}$. A $24 \mathrm{~mm}$ diameter reservoir was drilled with a 175 drill press in each sample, in which was inserted a $22 \mathrm{~mm}$ outer diameter copper tube with 176 horizontal slots in order to prevent sample swelling. A $18 \mathrm{~mm}$ diameter 177 polytetrafluoroethylene (PTFE) rod was also placed in the reservoir to minimise the solution 178 volume used for the experiment and the time required to reach diffusive equilibrium. 179 Solutions were analysed for anions $\left(\mathrm{Cl}^{-}, \mathrm{SO}_{4}{ }^{2-}\right.$ and $\left.\mathrm{Br}^{-}\right)$by ionic chromatography using a 180 DIONEX ICS-1000, and for stable isotopes $\left({ }^{18} \mathrm{O}\right.$ and $\left.{ }^{2} \mathrm{H}\right)$ using a Las Gatos Research LWIA- 
181 24IEP. The analytical uncertainties of these analysis are $\pm 5-10 \%$ for anions, $\pm 1 \%$ for ${ }^{2} \mathrm{H}$ 182 and $\pm 0.6 \%$ for ${ }^{18} \mathrm{O}$.

\section{3.4.2 Through diffusion}

184 Through diffusion cells consisted of a polypropylene sample holder, two polypropylene 185 reservoirs for liquid phase (upstream and downstream, with respective capacities of $180 \mathrm{~mL}$ 186 and $90 \mathrm{~mL}$ ), two supporting grids and two sampling openings. Six cylindrical samples of 187 approximatively $10 \mathrm{~mm}$ thickness and $30 \mathrm{~mm}$ diameter were prepared from core samples by 188 sawing with a diamond wire saw. These samples were confined between porous polyether 189 ether ketone (PEEK) grids in order to control clay mineral swelling and the assembly was 190 fixed to the sample holder using Sikadur ${ }^{(\mathbb{B}}$ epoxy adhesive. After a resaturation phase with 191 synthetic porewater, the solutions were replaced with fresh ones and the upstream reservoir 192 added with conservative radioactive tracers (HTO and ${ }^{36} \mathrm{Cl}^{-}$). The flux of radioactive species 193 between the reservoirs was monitored as a function of time by liquid scintillation using a 194 Packard Tri-carb 3100 TR counter. The accuracy of activity measurement is estimated at $195 \quad 6.4 \%$ for HTO and $3.5 \%$ for ${ }^{36} \mathrm{Cl}^{-}$.

\section{3.4.3 Modelling of the diffusion experiments}

197 Parallelepiped out diffusion and through diffusion experiments were modelled numerically 198 using the chemistry-transport coupled model code HYTEC (Van der Lee et al. 2003), which is 199 based on finite volumes method. In purely diffusive system and for mobile components, the 200 transport equation writes:

$$
\omega \frac{\partial c_{i}}{\partial t}=\operatorname{div}\left(D_{e} \nabla c_{i}\right)
$$

201 where $c_{i}$ is the total concentration of component $i, \omega[-]$ is the diffusion accessible porosity for 202 mobile components, and $D_{e}\left[\mathrm{~m}^{2} \mathrm{~s}^{-1}\right]$ is the effective diffusion coefficient with $D_{\mathrm{e}}=\omega D_{p}$, where $D_{p}$ is the pore diffusion coefficient accounting for the tortuosity of the porous media. 
204 For radial diffusion experiments, a numerical inversion of the semi-analytical solution given error function $S(\boldsymbol{m})$ :

$$
S(\boldsymbol{m})=\frac{1}{n} \sum_{i}\left(o b s_{i}-s i m_{i}\right)^{2}
$$

222 where $n$ is the number of measurements and $\boldsymbol{m}\left(m_{1} \ldots m_{n}\right)$ is the vector of model parameters.

223 The random walk is based on sorted values in the a priori probability density function (pdf) $224 \rho(\boldsymbol{m})$ of each parameter while the forward modelling identifies a set of parameters allowing a 225 good agreement between simulated and observed chloride values. This set of successful 
parameters samples the a posteriori joint pdf $\sigma(\boldsymbol{m})$ which describes the updated parameters distribution (after forward modelling and data comparison) yielding the best simulations. Then, marginal pdfs have to be identified for each parameter to estimate e.g., its mean value and associated uncertainty. A complex mathematical treatment is required to assess rigorously the marginal pdf of each parameter. Alternatively, the marginal distributions can be simply identified by a statistical treatment of all the parameters samples that satisfy an acceptance criterion (fraction of best simulations, misfit threshold). For the sake of simplicity, the marginal pdf were identified using the second alternative approach.

234 Let's now consider a current step of the MCMC algorithm characterised by a position $\boldsymbol{m}_{\boldsymbol{i}}$ of 235 the random walk in the parameter space, and a potentially new position $\boldsymbol{m}_{\boldsymbol{j}}$ created by means 236 of a random perturbation of $\boldsymbol{m}_{\boldsymbol{i}}$. The acceptance of the displacement from a former parameter 237 set $\boldsymbol{m}_{\boldsymbol{i}}$ to the posterior one $\boldsymbol{m}_{\boldsymbol{j}}$ follows the probabilistic rule (probability of acceptance $P$ ):

$$
P \begin{cases}1 & \text { if } S\left(\boldsymbol{m}_{i}\right)>S\left(\boldsymbol{m}_{j}\right) \\ \frac{L\left(\boldsymbol{m}_{j}\right)}{L\left(\boldsymbol{m}_{i}\right)}=\exp \left(-\frac{\Delta S}{\alpha}\right) & \text { if } S\left(\boldsymbol{m}_{i}\right)<S\left(\boldsymbol{m}_{j}\right)\end{cases}
$$

238 where $L(\boldsymbol{m})$ is the likelihood function defined by :

$$
L(\boldsymbol{m})=k \times e^{-\frac{S(m)}{\alpha}}
$$

239 where $k$ is a normative constant that ensures that the integral of $\sigma(\boldsymbol{m})$ over the parameter space 240 equals $1, \alpha$ is a convergence parameter to be set here by trial and error, and $\exp (-\Delta S / \alpha)=$ $241 \exp \left(-\left(S\left(\boldsymbol{m}_{\boldsymbol{j}}\right)-S\left(\boldsymbol{m}_{i}\right)\right) / \alpha\right)$

242 The first option in equation (3) just states that if the displacement yields a lower error between 243 the direct model results and the observations, the displacement is accepted. The second one 244 states that an unfavourable displacement can be accepted in order to leave local minimum 245 values of the objective function and to explore other regions of the parameter space. This 
second option is practically treated by sorting a value in an uniform distribution between 0

and 1: if it is lower than $\exp (-\Delta S / \alpha)$, which occurs with a probability $\exp (-\Delta S / \alpha)$, then the unfavourable displacement is accepted and the algorithm (Eq. 3) is satisfied. This algorithm globally favours the displacements within the parameter space in the direction of decreasing misfits. After a first convergence stage of the method, which consists in reaching the regions 251 of the parameter space where the error is minimum, the MCMC algorithm provides a set of 252 accepted parameters which allow the best simulations.

\section{Results and discussion}

$254 \quad 4.1$ Transport parameters

255 4.1.1 Porosities

256 Porosity values obtained from petrophysical analysis and diffusion experiments are reported 257 in Figure 4.

a) Water-accessible porosity

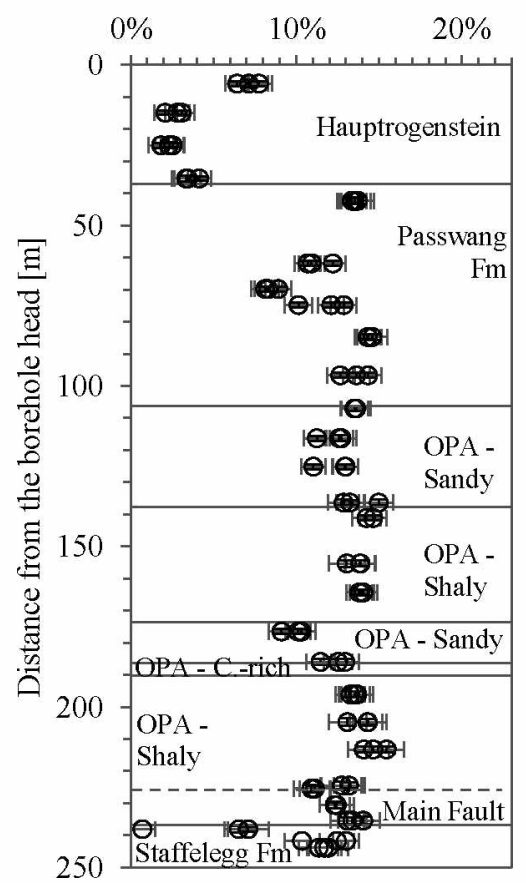

b) Accessible porosity Relative error $\pm 5 \%$

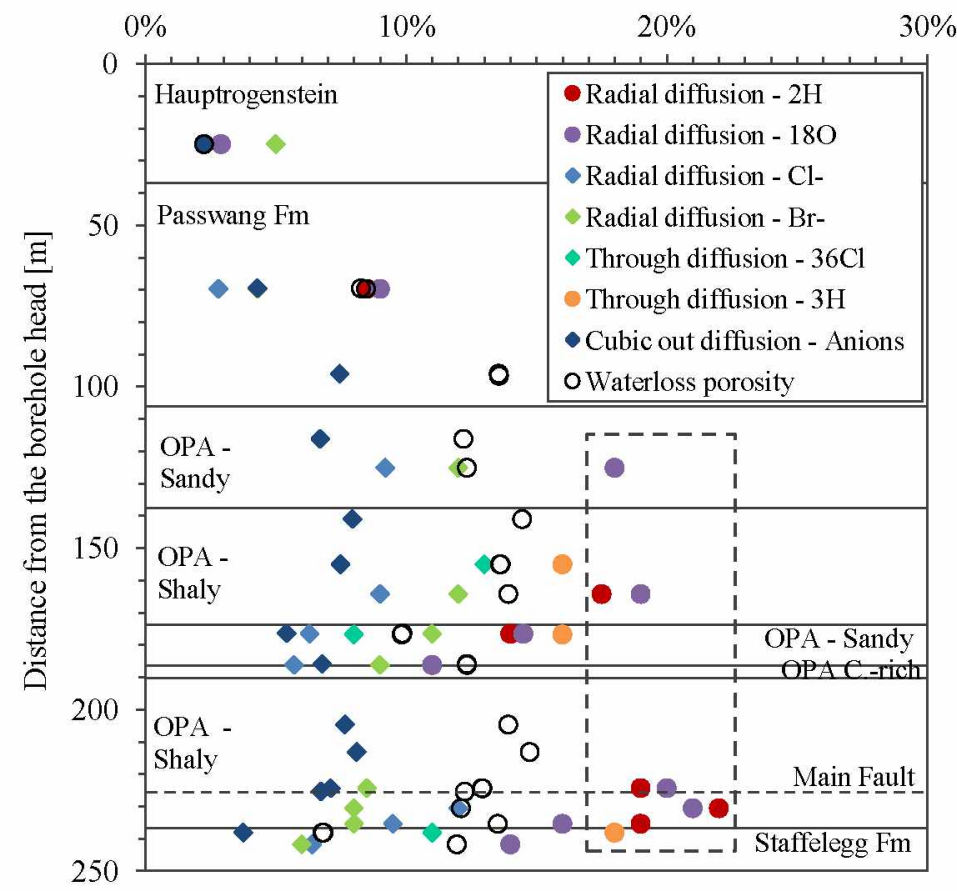

259 Figure 4: a) Water accessible porosity acquired by oven-drying at $105^{\circ} \mathrm{C}$ of BDB-1 borehole samples and b) accessible porosity to anions $\left(\mathrm{Cl}^{-}, \mathrm{Br}^{-}\right)$, radioactive tracers $\left(\mathrm{HTO},{ }^{36} \mathrm{Cl}^{-}\right)$and 
261 stable water isotopes $\left({ }^{3} \mathrm{H},{ }^{18} \mathrm{O}\right)$ determined by laboratory-scale diffusion experiments. Values

266 267 268 269

framed by a dashed line are probably overestimated due to swelling or microcracks.

The mean water accessible porosity determined by density measurements is $13.0 \%$ in the Opalinus Clay, with a lower average porosity of $12.0 \%$ in the sandy facies compared to the shaly facies, which shows a mean porosity of $13.5 \%$. These values are lower than the mean value of $18 \%$ suggested by previous studies performed at the Mont Terri tunnel level (Bossart et al. 2017). The Passwang Formation presents slightly lower porosity values ranging between $8.1 \%$ and $14.6 \%$ with a mean value of $12.2 \%$. The Hauptrogenstein is characterised by the lowest porosity with a mean value of $3.9 \%$.

Except for the carbonate-rich sandy facies, porosity values obtained by radial diffusion for stable water isotopes in the Opalinus Clay (up to $22 \%$ ) are higher than the values obtained by density measurements (maximum value of $15 \%$ ). Sample preparation steps, such as drilling, may have brought additional porosity by creating microcracks. Values obtained for ${ }^{2} \mathrm{H}$ and ${ }^{18} \mathrm{O}$ are globally comparable and the anion exclusion (ratio of anion to water accessible porosities) is in the range of $51 \%$ to $55 \%$ in the OPA shaly facies and between $45 \%$ and $51 \%$ in the sandy facies. These results are consistent with the ratio of $55 \%$, which was chosen in out diffusion experiments to calculate anion contents in porewater and based on literature data (Pearson et al. 2003). Chloride and bromide diffusion accessible porosities are also comparable with values ranging between $6 \%$ and $12 \%$ and a best estimate at $8 \%$.

\subsubsection{Diffusion coefficients}

Deduced from radial diffusion experiments, chloride and bromide effective diffusion coefficient parallel to the bedding are in the order of $4.0 \times 10^{-11} \mathrm{~m}^{2} \mathrm{~s}^{-1}$ in the Opalinus Clay, which is in good agreement with the range of $1.7 \times 10^{-11}$ to $4.5 \times 10^{-11} \mathrm{~m}^{2} \mathrm{~s}^{-1}$ for bromide and $1.8 \times 10^{-11}$ to $6.8 \times 10^{-11} \mathrm{~m}^{2} \mathrm{~s}^{-1}$ for chloride reported in previous studies (Bossart et al. 2011). Reasonable values from $3.0 \times 10^{-11}$ to $1.1 \times 10^{-10} \mathrm{~m}^{2} \mathrm{~s}^{-1}$ are obtained for stable water isotopes. 
Values obtained by through diffusion experiments are also in good agreement with literature data. In the Opalinus Clay shaly facies, values of $9.6 \times 10^{-11} \mathrm{~m}^{2} \mathrm{~s}^{-1}$ for tritium and $1.4 \times 10^{-11}$ $\mathrm{m}^{2} \mathrm{~s}^{-1}$ for ${ }^{36} \mathrm{Cl}$ are obtained parallel to the bedding. In the sandy facies, simulations give $1.9 \times$ $10^{-11} \mathrm{~m}^{2} \mathrm{~s}^{-1}$ for tritium and $5.1 \times 10^{-12} \mathrm{~m}^{2} \mathrm{~s}^{-1}$ for ${ }^{36} \mathrm{Cl}$ perpendicular to the bedding (Figure 5).

290 Due to experimental artefacts linked to sample preparation, only three out of the six through 291 diffusion cells provided relevant data.

292 Alternative formula for the anion exclusion ratio is given by Jacquier et al. (2013) and writes:

$$
P_{a}=\frac{D_{e}[H T O] / D_{e}\left[{ }^{36} \mathrm{Cl}^{-}\right]}{D_{0}[H T O] / D_{0}\left[{ }^{36} \mathrm{Cl}^{-}\right]}
$$

293 where $D_{e}\left[\mathrm{~m}^{2} \mathrm{~s}^{-1}\right]$ is the effective diffusion coefficient and $D_{0}\left[\mathrm{~m}^{2} \mathrm{~s}^{-1}\right]$ is the diffusion 294 coefficient in free water, equal to $2.008 \times 10^{-9} \mathrm{~m}^{2} \mathrm{~s}^{-1}$ for HTO and $1.771 \times 10^{-9} \mathrm{~m}^{2} \mathrm{~s}^{-1}$ for $\mathrm{Cl}^{-}$at $29525^{\circ} \mathrm{C}$ (Mills and Lobo, 1989).

296 Using equation (5), the diffusion anion exclusion deduced from through diffusion experiment 297 is equal to 5.9 in the Opalinus Clay shaly facies, and 3.2 in the sandy facies.

298 The diffusion anisotropy ratio is the ratio between the effective diffusion coefficients parallel 299 and perpendicular to the bedding. Based on out diffusion experiments, a low anisotropy ratio 300 of 2.4 was estimated for chloride effective diffusion coefficient in the Opalinus Clay sandy 301 facies, which is lower than the value of 4 reported by Van Loon et al. (2004) on a shaly facies 302 sample. Anisotropy of diffusive parameters could not be determined in the shaly facies due to sample cracking and other unloading artefacts. 
Effective diffusion coefficient $\left[\mathrm{m}^{2} / \mathrm{s}\right]$

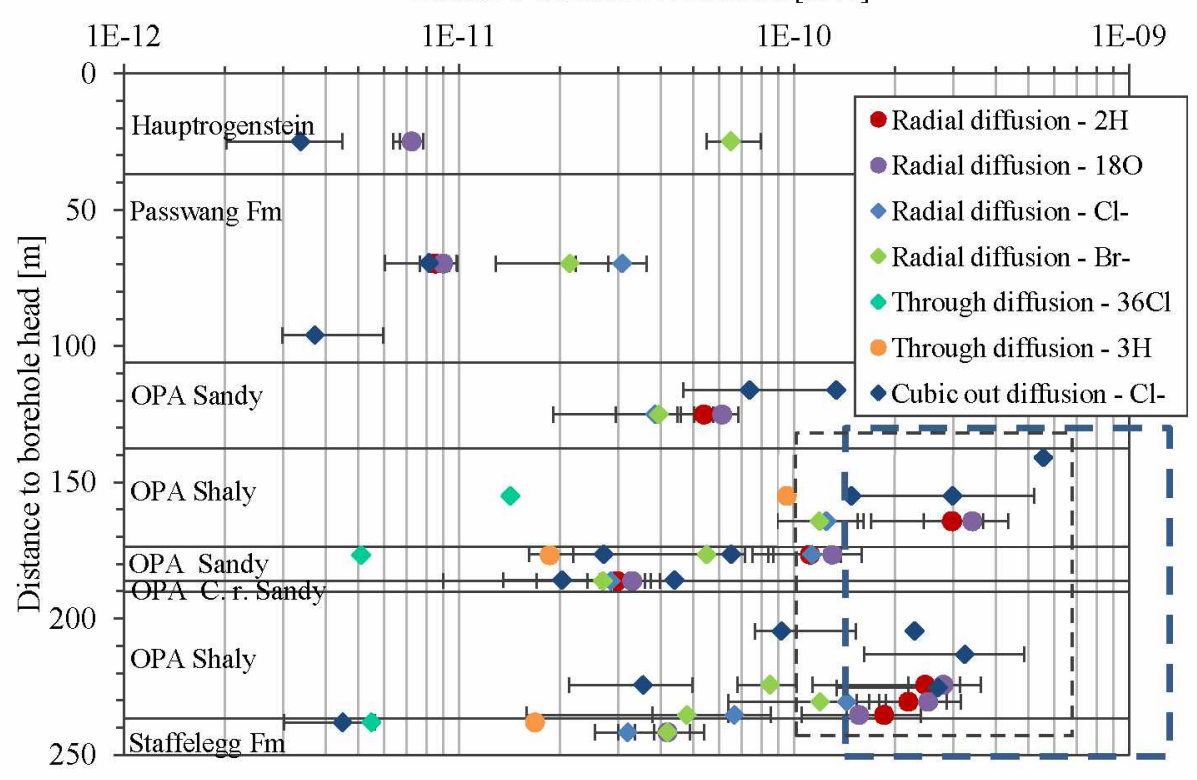

305 Figure 5: Effective diffusion coefficients acquired on BDB-1 borehole samples. Values

306 framed by a dashed line are probably overestimated due to swelling or microcracks.

307 4.2 Anion profiles

308 Chloride, bromide and sulphate profiles acquired by leaching and out diffusion experiments 309 on BDB-1 samples are presented in Figure 6 and confirm the vertical variability of porewater 310 composition along the stratigraphic column.

a)

$\left[\mathrm{Cl}^{-}\right]\left[\mathrm{mg} \mathrm{L}^{-1}\right]$
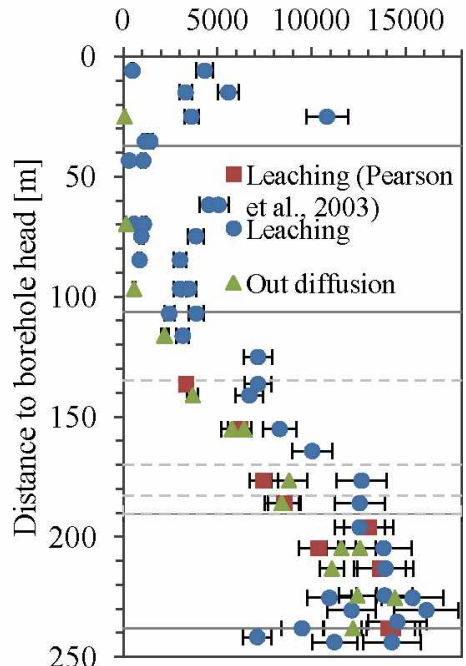

b)

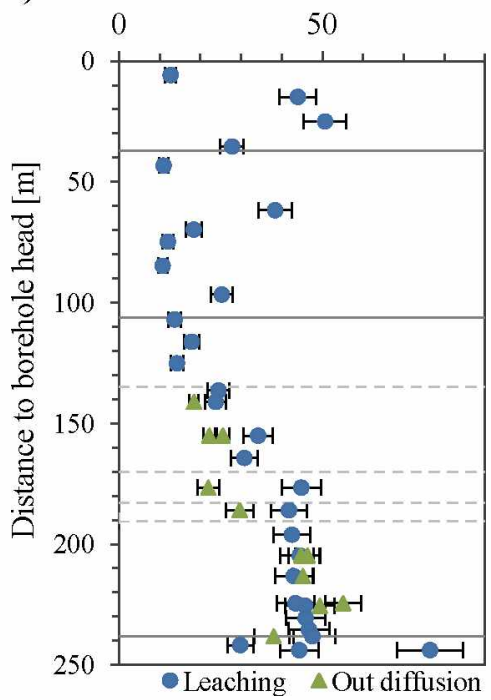

c) $\quad\left[\mathrm{SO}_{4}{ }^{2-}\right]\left[\mathrm{mg} \mathrm{L}^{-1}\right]$

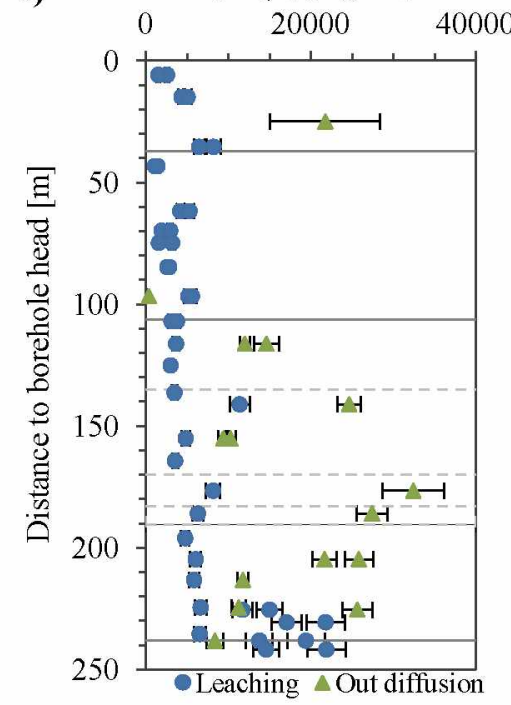


313 Figure 6: Chloride, bromide and sulphate profiles acquired along BDB-1 borehole by leaching 314 experiments and out diffusion tests.

315 Chloride and bromide values obtained by aqueous leaching are systematically higher 316 compared to out diffusion results. Higher values of halides given by aqueous leaching 317 compared to out diffusion are likely due to mineral dissolution or release of elements initially 318 contained in inaccessible porosity. However, the two methods reveal similar curved profiles 319 with increasing chlorinity towards the basal part of the Opalinus Clay (up to $16.1 \mathrm{~g} \mathrm{~L}^{-1}$ from 320 leaching experiments). Out diffusion experiments give a range between $2.1 \pm 0.3 \mathrm{~g} \mathrm{~L}^{-1}$ and $321 \quad 14.4 \pm 1.0 \mathrm{~g} \mathrm{~L}^{-1}$ for chloride contents with maximum concentrations found in the basal shaly 322 facies of the Opalinus Clay. The sulphate profile along BDB-1 borehole also shows an 323 increasing trend with depth, but even when extraction was performed under anoxic conditions, oxidation had a major effect on measured concentrations. Artificial increase of sulphate contents can be induced by artefacts linked to experimental procedures: pyrite oxidation 326 during the sample preparation or equilibration process, and dissolution of sulphate-bearing 327 minerals such as gypsum or celestite (Pearson et al., 2003; Wersin et al., 2013). Previous 328 studies conducted at the tunnel level also concluded to a maximum value ranging from 13.6 to $32914.4 \mathrm{~g} \mathrm{~L}^{-1}$ for chloride content, found at the limit between the Opalinus Clay and the 330 Staffelegg Formation (Pearson et al. 2003). The halide concentration ratios are consistent with 331 a marine origin of the Opalinus Clay porewater.

3324.3 Chloride profile modelling

333 4.3.1 Modelling assumptions and scenario

Although the predominant character of diffusion among other transport processes in low 335 permeability formations is generally claimed, such assumption, which greatly simplifies transport numerical calculations, must be verified using the Peclet number (Soler, 2001): 


$$
P e=\frac{q L}{D_{e}}
$$

337 where $q\left[\mathrm{~m} \mathrm{~s}^{-1}\right]$ is the specific discharge (Darcy's velocity), $L[\mathrm{~m}]$ is a characteristic distance 338 for transport, here taken to be the formation half thickness, and $D e\left[\mathrm{~m}^{2} \mathrm{~s}^{-1}\right]$ is the effective 339 diffusion coefficient. It is classically stated that for $\mathrm{Pe}<1$, diffusion dominates over advection 340 and advection is dominant over chemical diffusion if $\mathrm{Pe}>1$. However, in their discussion of 341 transport phenomena in low permeability environments, Huysmans and Dassargues (2005) 342 show that for Peclet numbers (Eq. 6) as high as 10, numerically simulated salinity profiles 343 considering advection and diffusion or diffusion alone only differed by $10 \%$ pointing to a 344 negligible advective contribution. Consequently, one can consider that below a value of 10 for $345 P e$, diffusion models are sufficiently accurate for salinity profile interpretations.

The Opalinus Clay formation is characterized by maximum pressures (or hydraulic head h) 347 and chlorinity values within the formation yielding corresponding differences with the 348 surrounding aquifers of at least 5 bars $(\Delta \mathrm{h}=50 \mathrm{~m})$ and $\Delta \mathrm{c}=0.42 \mathrm{~mol} \mathrm{~L}^{-1}$ respectively. A 349 monotonic cross-formational temperature difference of $8^{\circ} \mathrm{C}$ per $100 \mathrm{~m}$ is also observed.

350 Considering that osmotic processes are at work in the Opalinus Clay, the 1D Darcy's velocity 351 accounting for osmotic terms can be expressed as (Gonçalvès et al., 2015):

$$
q=-K \frac{\partial h}{\partial z}+\frac{v R T \varepsilon_{c} K}{\rho g} \frac{\partial c}{\partial z}-\frac{\varepsilon_{T}}{\rho g} K \frac{\partial T}{\partial z}
$$

352 where $K\left[\mathrm{~m} \mathrm{~s}^{-1}\right]$ is the cross-formational hydraulic conductivity, $\mathrm{z}$ is the axis perpendicular to 353 the bedding, $h[\mathrm{~m}]$ is the hydraulic head, $\rho$ is the porewater density $\left[\mathrm{kg} \mathrm{m}^{-3}\right], g\left[9.81 \mathrm{~m} \mathrm{~s}^{-2}\right]$ is 354 the gravitational acceleration, $\varepsilon_{c}[-]$ and $\varepsilon_{T}\left[\mathrm{~Pa} \mathrm{~K}^{-1}\right]$ are respectively the chemical osmotic 355 efficiency and the thermo-osmotic coefficient, $v$ is the number of dissociated species for a salt 356 (e.g. 2 for $\mathrm{NaCl}$ ), $R\left[8.32 \mathrm{~m}^{3} \mathrm{~Pa} \mathrm{~K}^{-1} \mathrm{~mol}^{-1}\right]$ is the gas constant, $T[\mathrm{~K}]$ is the temperature, and $c$ 
$357\left[\mathrm{~mol} \mathrm{~m}^{-3}\right]$ is the chloride concentration. Note that for this first-order calculation, no gravity 358 effect due to salinity is considered enabling the use of the hydraulic head $h$.

359 The first term in the right-hand side of Equation (7) is related to purely darcian fluid flow, the 360 second and third terms to the chemical and thermal osmosis, i.e. fluid flow driven by salinity 361 and temperature gradients. The petrophysical parameters of the Opalinus clay together with 362 the thermo-osmotic model by Gonçalvès et al. (2015) points to a negligible thermo-osmotic 363 term here. For the two remaining terms, simple gradients given by $\Delta h / L$ and $\Delta c / L$ can be 364 introduced in Eqs (6) and (7). Peclet calculations require equivalent transport parameters 365 (harmonic means across the formation, perpendicular to the bedding). Using the data of this 366 study and of Yu et al. (2017), a harmonic mean of $10^{-11} \mathrm{~m}^{2} \mathrm{~s}^{-1}$ and $1.85 \times 10^{-13} \mathrm{~m} \mathrm{~s}^{-1}$ is found 367 for $D_{e}$ and $K$. Using these values for an equivalent $\mathrm{NaCl}(v=2)$ system and $\varepsilon_{c}$ between 0.036 26

372 The paleohydrogeological evolution was chosen accordingly to the conclusions of Bossart 
1 samples and described in section 5.1. Exhumation times $t_{0}$ and $t_{1}$ together with the initial chlorinity are used for boundary and initial conditions definition of the $1 \mathrm{D}$ diffusion model. At initial time $t_{0}$, the chlorinity is set to $C_{0}$ within the Opalinus clay, the upper and lower concentration boundary conditions are 0 and $C_{0}$, respectively. Then, when the simulation time reaches $t_{l}$, the lower boundary condition is set to zero. These boundary conditions allow simulating diverging diffusive mass transport from the Opalinus Clay towards first the upper aquifer alone then towards both aquifers. The model takes into accounts 7 formations showing different properties listed in Table 1.

\subsubsection{Modelling results}

The parameters to be calibrated must be chosen carefully since for more than 10 parameters, implementing MCMC methods becomes hazardous (large time- and cpu-consuming, convergence issues). However, under the assumption of purely diffusive mass transport, since the porosity intrinsically appears $\left(D_{e}=\omega D_{p}\right)$ in both sides of Equation (1), this parameter does not impact calculated chlorinity profiles which are only controlled by the pore diffusion coefficient. Therefore, porosity was not considered in our inverse modelling and was kept constant for each formation. From a practical standpoint, the calibrated parameters were the cross-formational effective diffusion coefficient for each of the 7 formations $D_{e}$ (in fact $D_{p}$ since $\omega$ is fixed, see above), $t_{0}, t_{l}$ and $C_{0}$ which are all considered uncertain. Uniform a priori distributions were considered for these 10 parameters using lower and upper boundaries described in Section 4.3.1 for $t_{0}, t_{1}$ and $C_{0}$, and boundaries encompassing the measurements for the 7 formation $D_{e}$ values (see Table 1)

In the course of the MCMC inversion process involving 10 parameters (a priori values in Table 1), the misfit function reached a plateau after about 2000 iterations for 100000 performed iterations (Figure A.1, Appendix A). Only about 800 random moves were accepted, 
indicating a relatively low number of parameter sets that fit the experimental data. The sets of parameters leading to the $5 \%$ lower misfit values were used to establish the a posteriori marginal distributions of the ten parameters shown in Fig 2.A of Appendix A. Both multimodal and unimodal distributions are obtained. Multimodal distributions were fitted by gaussian mixture distributions, all unimodal variables were fitted by a gaussian model except for $C_{0}$ that is described by a $\log$ normal distribution (see Appendix A). Mean values and 95\% confidence intervals for each parameters were calculated using the fitted distributions (see Table 1). For multimodal distributions, the weights and means of each fitted normal 414 distribution component are used to calculate an "overall mean" for a given parameter as the 415 weighted average of the mean values (see Appendix A). Therefore, the relative importance of 416 each gaussian distribution within the gaussian mixture is respected. Note that the low number 417 of sampled values in the parameter space is likely a limitation for the a posteriori marginal 418 pdfs identification method described in Section 3.5. However, taking more samples (40\% of 419 accepted displacements) yields the same type of marginal distributions but with slightly 420 different statistical parameters and a larger misfit when the mean parameters values are used 421 in a direct simulation.

422 Table 1: Input parameters and associated uncertainties involved in the MCMC inversion 423 process. Accessible porosities and formation thicknesses were kept constant. CI stands for 424 Confidence Interval.

\begin{tabular}{|c|c|c|c|c|c|}
\hline \multirow[b]{2}{*}{ Formation } & \multirow[b]{2}{*}{$\begin{array}{c}\text { Thickness } \\
\text { [m] }\end{array}$} & \multirow[b]{2}{*}{$\begin{array}{c}\omega \\
\text { [vol.\%] }\end{array}$} & \multicolumn{3}{|c|}{$\operatorname{De}\left[\mathrm{m}^{2} / \mathrm{s}\right]\left(\times 10^{-11}\right)$} \\
\hline & & & Measurements & A priori & $\begin{array}{c}\text { A posteriori } \\
\text { Mean } \\
\text { and } 95 \% \mathrm{CI}\end{array}$ \\
\hline Passwang Formation & 69 & 7.5 & $\begin{array}{c}\mathrm{D}_{\mathrm{e}}^{7}: 0.817 \\
\quad \pm 0.2\end{array}$ & {$\left[10^{-1}-20\right]$} & $\begin{array}{c}2.66 \\
{[1.51 ; 4.81]}\end{array}$ \\
\hline $\begin{array}{l}\text { OPA - } \\
\text { Sandy facies }\end{array}$ & 29 & 6.9 & $\begin{array}{c}\mathrm{D}_{\mathrm{e}}^{6}: 7.38 \\
\quad \pm 4.36\end{array}$ & {$\left[10^{-1}-20\right]$} & $\begin{array}{c}6.55 \\
{[3.92 ; 11.61]}\end{array}$ \\
\hline $\begin{array}{l}\text { OPA - } \\
\text { Shaly facies }\end{array}$ & 35 & 7.6 & $\begin{array}{c}\mathrm{D}_{\mathrm{e}}^{5}: 0.597 \\
\quad \pm 0.2\end{array}$ & {$\left[10^{-1}-20\right]$} & $\begin{array}{c}0.30 \\
{[0.18 ; 0.41]}\end{array}$ \\
\hline OPA - & 14 & 5.4 & $\mathrm{D}_{\mathrm{e}}^{4}: 2.71$ & {$\left[10^{-1}-20\right]$} & 1.91 \\
\hline
\end{tabular}


Sandy facies

OPA -

Carbonate-rich Sandy facies

OPA -

Shaly facies

Staffelegg Formation

Parameter $\pm 1.9$

$\mathrm{D}_{\mathrm{e}}{ }^{3}: 2.04$

$\pm 0.68$

$\mathrm{D}_{\mathrm{e}}^{2}: 3.56$

$\pm 1.42$

$\mathrm{D}_{\mathrm{e}}{ }^{1}: 0.451$

$\pm 0.132$
[0.59; 4.12]

2.91

$[0.39 ; 4.84]$

0.33

[0.04;0.62]

0.59

[0.15;1.04]

Value Range

A posteriori

Activation time [Ma]

$\begin{array}{rcc}\begin{array}{r}\text { Dogger aquifer } \\ \text { (upper boundary) }\end{array} & -5 & {[-10.5 ;-1.2]} \\ \text { Lias aquifer } & -0.25 & {[-0.5 ;-0.2]} \\ \text { (lower boundary) } & -0.25 & \end{array}$

$-4.54$

$[-6.77 ; 1.7]$

$-0.24$

$[-0.3 ;-0.2]$

19

Initial chlorinity $\left[\mathrm{g} \mathrm{L}^{-1}\right]$

19

[14;23]

8

As shown in Figure $7 \mathrm{a}$, the simulation of diffusion for chloride matches fairly well the experimental data considering the mean a posteriori values for the parameters (Table 1). Except for two diffusion coefficients values (Passwang Formation and Opalinus Clay basal shaly facies), the fitted parameters are highly consistent with the measurements and 429 exhumation time expectations (Figure $7 b$ ). The misfit for diffusion coefficients can be due to 430 an imperfect mechanical confining of the Opalinus Clay sample leading to an overestimation 431 of the measured $D_{e}$ for the Opalinus Clay shaly facies. On the other hand, the Passwang 432 Formation is more heterogeneous compared to the different facies of the Opalinus Clay. 433 Lithostratigraphic investigation carried out by Hostettler et al. (2017) on BDB-1 drillcores 434 showed that this formation exhibits variable lithology (silty to fine sandy marls, quartz sand 435 and biodetrital sandy limestones, ferruginous limestones, iron oolithic marls and limestones).

436 The number of samples investigated in laboratory-scale diffusion experiments was likely 437 insufficient to reflect this variability in the present study. 
a)

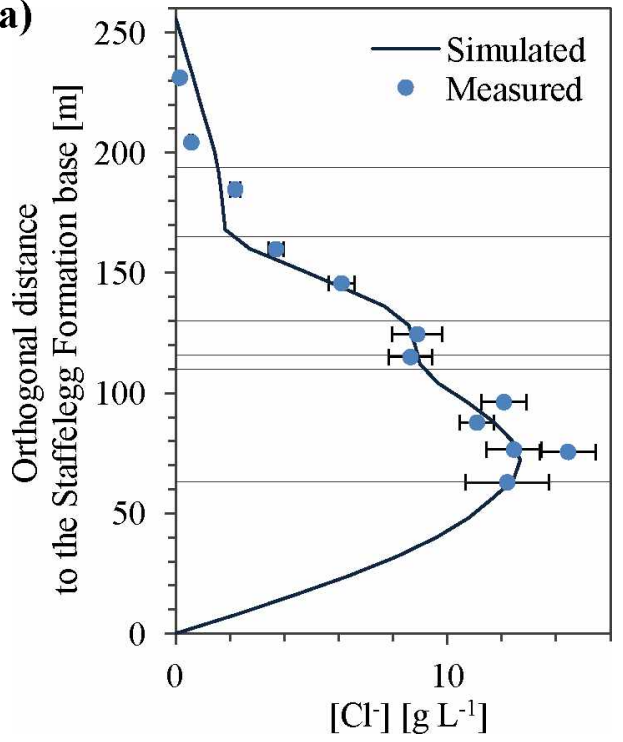

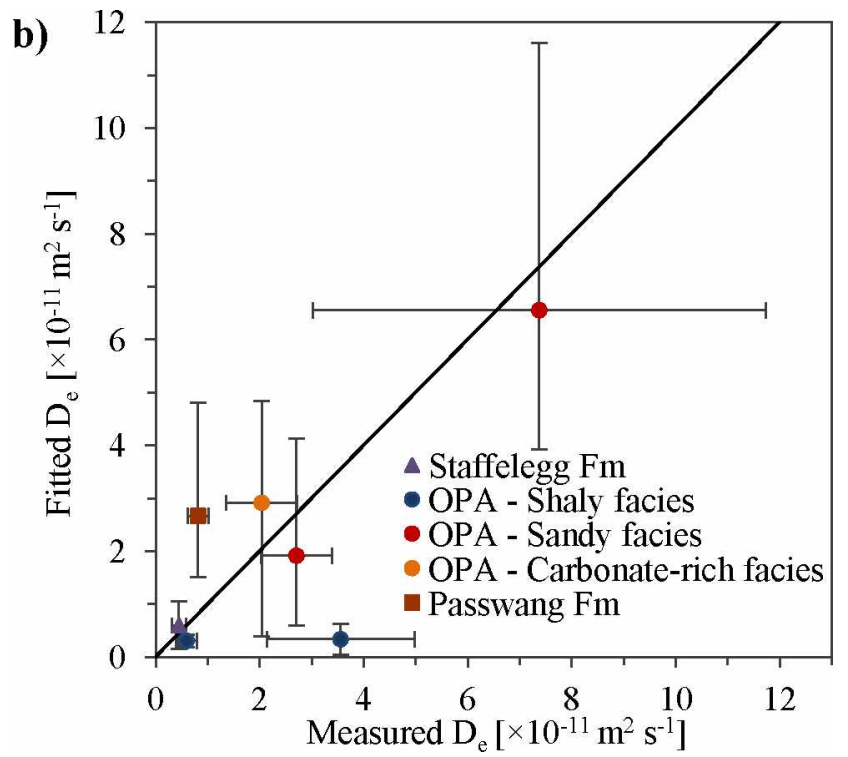

439 Figure 7: Comparison between a) experimental and simulated chloride profile obtained with 440 the mean a posteriori values for the parameters and b) experimental and fitted diffusion 441 coefficients, error bars represent $95 \%$ confidence interval.

442 The modelling results are globally consistent with previous studies carried out at the Mont 443 Terri rock laboratory. A lower equivalent effective diffusion coefficient for anions of $4.6 \times$ $44410^{-12} \mathrm{~m}^{2} \mathrm{~s}^{-1}$ was used in Mazurek et al. (2011) for the Opalinus Clay and the directly adjacent 445 formations, whereas different diffusion coefficient values were considered for each unit along 446 the rock sequence in the present study. A higher cross-formational equivalent diffusion 447 coefficient of $6.3 \times 10^{-12} \mathrm{~m}^{2} \mathrm{~s}^{-1}$ for the Opalinus Clay explains the shorter time obtained for 448 the adjacent aquifers activation in comparison with the study of Mazurek et al.(2011): $4.5 \mathrm{Ma}$ 449 compared to $6 \mathrm{Ma}$ for the upper aquifer and $0.246 \mathrm{Ma}$ compared to $0.5 \mathrm{Ma}$ for the lower 450 aquifer. However, the activation age at -4.54 Ma proposed here is close to one of the major 451 morpho-tectonic event proposed by Kuhlemann and Rahn (2013) at $-4.2 \mathrm{Ma}$.

\section{Conclusions}

453 An integrated study from BDB-1 borehole samples characterisation on the Opalinus Clay 454 transport capabilities and transport modelling was performed. Petrophysical analysis enabled 
the acquisition of water accessible porosity, grain density and water contents along the rock sequence. Out diffusion and aqueous leaching techniques were used to obtain chloride concentrations of porewater in the Opalinus Clay and its bounding formations. Effective diffusion coefficients and diffusion accessible porosities were also investigated by radial diffusion and through diffusion experiments.

460 The measured chloride contents are in good agreement with previous investigation performed 461 at the Mont Terri tunnel level, and show an asymmetric bell-shaped trend increasing to a high 462 chloride concentration of $14.4 \mathrm{~g} \mathrm{~L}^{-1}$ towards the bottom of the Opalinus Clay. Moreover, 463 chloride to bromide ratios reflect a marine signature in the clay rock. The chloride profile 464 suggests a diffusive exchange between the argillaceous formation and the adjacent aquifers, 465 with deferred activation times of the fresh-water sources linked to the surface erosion of the 466 geological formations. This scenario was implemented in a Monte Carlo Markov Chain 467 algorithm, which enabled to assess the best fitting set of parameters (initial chloride content, 468 aquifer activation times and diffusion coefficients) and associated confidence intervals 469 explaining the present-day chloride profile. Experimental and simulated data are comparable 470 for respective diffusion times of 4.54 Ma and 0.246 Ma between the Opalinus Clay and the 471 Dogger (overlying) and Liassic (underlying) limestones.

472 The present study confirms the paleohydrogeological evolution of the Mont Terri site from 473 the folding of the Jura Mountains. This scenario is fundamental to constrain our future 474 transient modelling of the overpressure regime observed in the Opalinus Clay to fully 475 characterise transport processes in this formation. 


\section{Acknowledgments}

477 This study was performed in the framework of the Deep Borehole experiment, financed by six 478 partners of the International Mont Terri Consortium (Swisstopo, NAGRA, BGR, GRS, 479 NWMO, IRSN).

$480 \quad$ Appendix A

481 The convergence of the MCMC approach is characterised by a sharp decrease of the misfit 482 function value from almost 7 to 1.5 on average after 2000 iterations (almost 200 accepted 483 movements) of the random walk as shown in Figure A.1

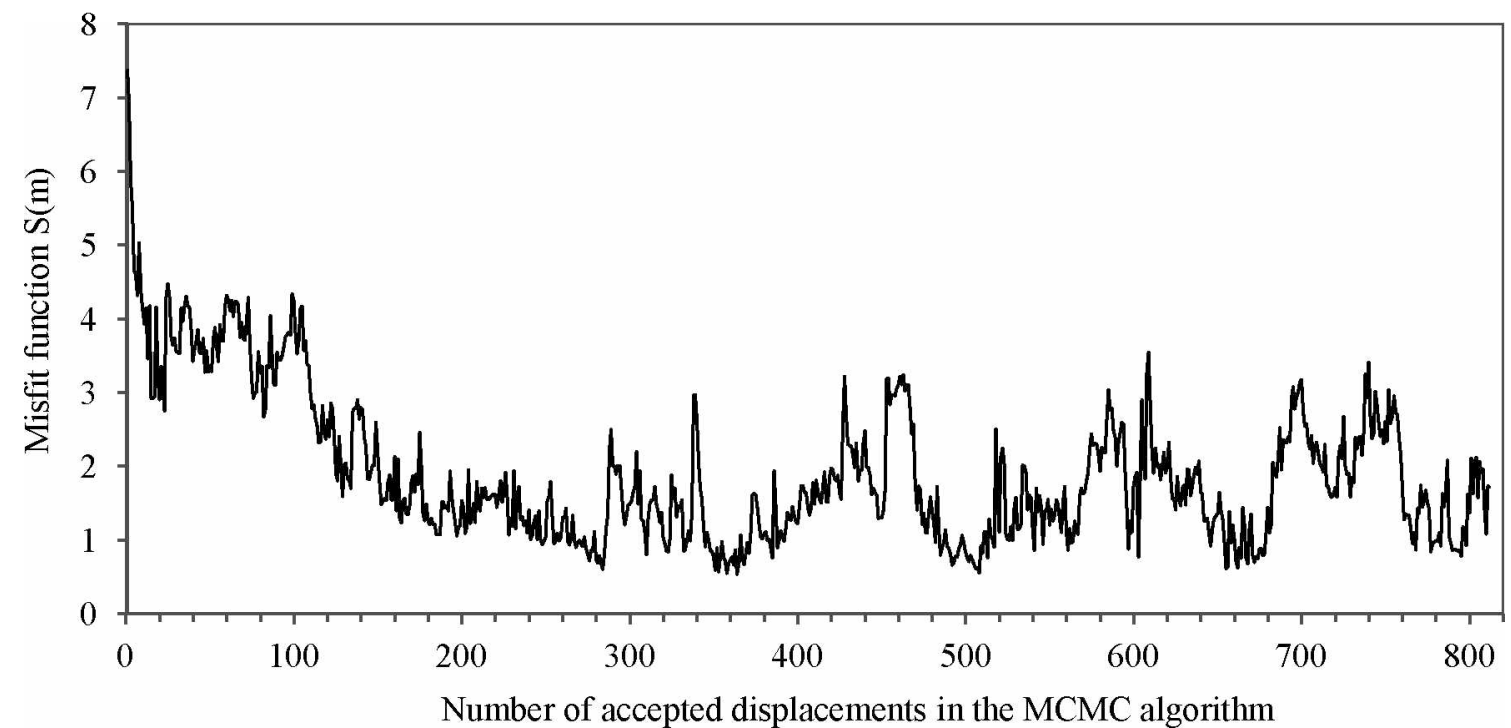

485 Figure A.1: Misfit function as a function of the number of accepted displacements in the 486 MCMC algorithm.

487 The sets of parameters leading to the $5 \%$ lower misfit values (errors lower than 0.7 ) were used 488 to establish the a posteriori marginal distributions (Figure A.2). 


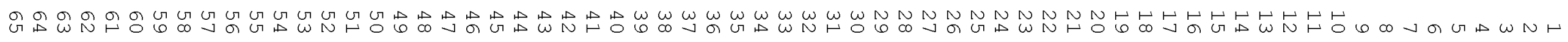
영
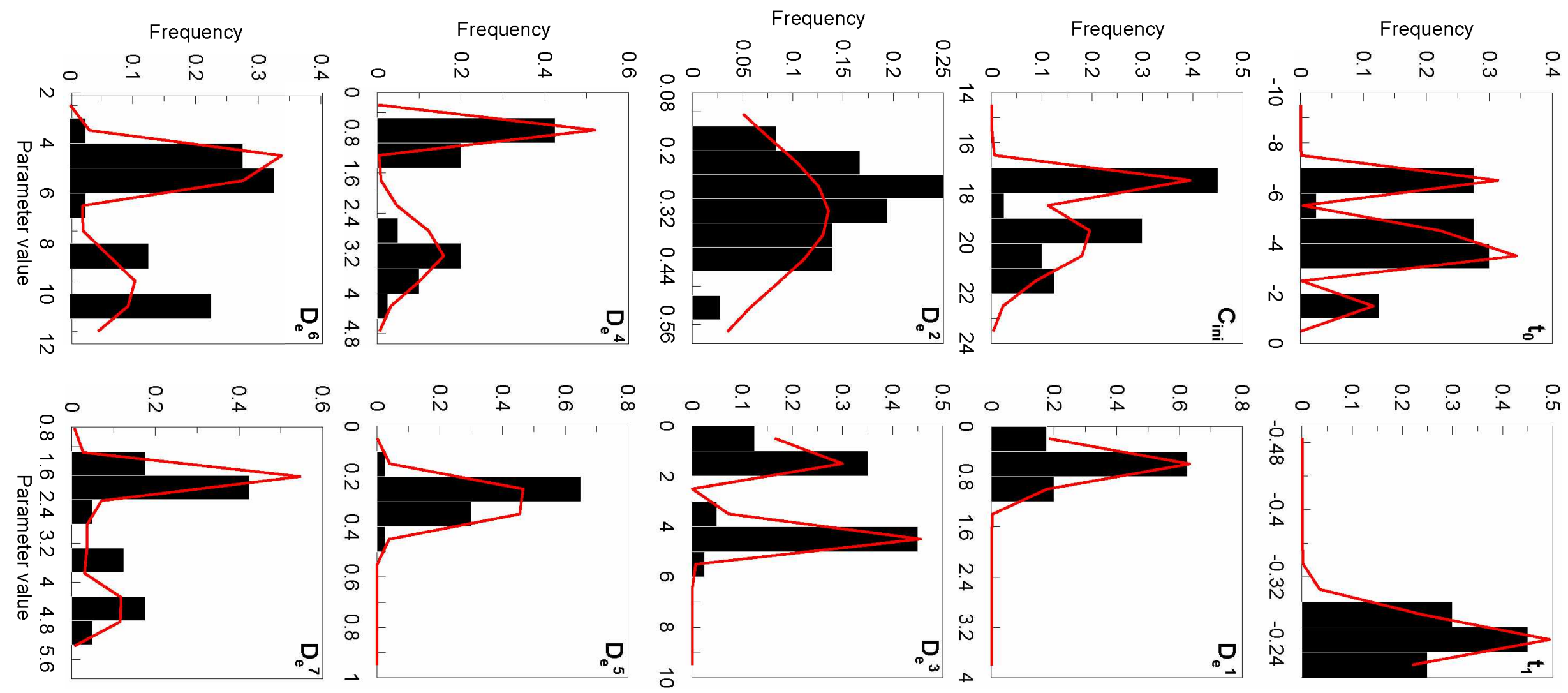
Figure A.2: A posteriori distributions (pdfs) for each parameter of the diffusion model.

491 Parameters values in $\left[\times 10^{-11} \mathrm{~m}^{2} \mathrm{~s}^{-1}\right]$ for $D e$, [ $\left.\mathrm{g} \mathrm{L}^{-1}\right]$ for $C_{0}$, and $[\mathrm{Ma}]$ for $t_{0}$ and $t_{l}$. The 492 histograms results from the MCMC approach (Section 3.5). In red, the fitted theoretical 493 distributions (Gaussian mixtures: $t_{0}, C_{0}, D_{e}{ }^{3}, D_{e}{ }^{4}, D_{e}{ }^{6}$, and $D_{e}{ }^{7}$, Gaussian: $D_{e}{ }^{1}, D_{e}{ }^{2}$, and $D_{e}^{5}$, 494 and Lognormal: $\left.t_{1}\right)$

495 Multimodal distributions were fitted by gaussian mixture distributions:

$$
\alpha G\left(\mu_{1}, \sigma_{1}\right)+\beta G\left(\mu_{2}, \sigma_{2}\right)+\gamma G\left(\mu_{3}, \sigma_{3}\right)
$$

496 where $G\left(\mu_{i}, \sigma_{i}\right)_{i=\{1, \ldots, 3}$ are Gaussian distributions and $\alpha, \beta$, and $\gamma$ are the respective weights. The 497 fitted distribution parameters are listed in Table A.1.

498 Table A.1: Parameters of fitted pdf with effective diffusion coefficients $D_{e}\left[\times 10^{-11} \mathrm{~m}^{2} \mathrm{~s}^{-1}\right]$, 499 activation times $t_{0}$ and $t_{1}[\mathrm{Ma}]$, and initial chloride concentration $C_{0}\left[\mathrm{~g} \mathrm{~L}^{-1}\right]$.

\begin{tabular}{cccccccccc}
\hline Variable & $\alpha$ & $\beta$ & $\gamma$ & $\mu_{1}$ & $\sigma_{1}$ & $\mu_{2}$ & $\sigma_{2}$ & $\mu_{3}$ & $\sigma_{3}$ \\
\hline $\mathrm{t}_{0}$ & 0.32 & 0.56 & 0.12 & -6.45 & -3.95 & -1.78 & 0.19 & 0.22 & 0.10 \\
$\log \left(-\mathrm{t}_{1}\right)$ & 1 & 0 & 0 & -0.61 & 0.04 & - & - & - & - \\
$\mathrm{C}_{0}$ & 0.37 & 0.63 & 0 & 17.48 & 19.87 & 1.22 & 0.09 & - & - \\
$\mathrm{D}_{\mathrm{e}}{ }^{1}$ & 1 & 0 & 0 & 0.60 & 0.22 & - & - & - & - \\
$\mathrm{D}_{\mathrm{e}}{ }^{2}$ & 1 & 0 & 0 & 0.33 & 0.14 & - & - & - & - \\
$\mathrm{D}_{\mathrm{e}}{ }^{3}$ & 0.16 & 0.3 & 0.54 & 0.48 & 1.74 & 4.33 & 0.08 & 0.08 & 0.3 \\
$\mathrm{D}_{\mathrm{e}}{ }^{4}$ & 0.53 & 0.47 & 0 & 0.75 & 3.18 & 0.57 & 0.10 & - & - \\
$\mathrm{D}_{\mathrm{e}}{ }^{5}$ & 1 & 0 & 0 & 0.3 & 0.06 & - & - & - & - \\
$\mathrm{D}_{\mathrm{e}}{ }^{6}$ & 0.67 & 0.33 & 0 & 4.91 & 9.83 & 1.24 & 0.55 & - & - \\
$\mathrm{D}_{\mathrm{e}}{ }^{7}$ & 0.58 & 0.22 & 0.2 & 1.86 & 3.08 & 4.58 & 0.14 & 1.19 & 0.14 \\
\hline
\end{tabular}




\section{References}

2

3

Bensenouci, F., 2010. Apport des traceurs naturels à la compréhension des transferts au sein des formations argileuses compactées. Thesis, Université Paris-Sud XI, Orsay, France, 194 pp.

Bensenouci, F., Michelot, J.L., Matray, J.M., Savoye, S., Tremosa, J., Gaboreau, S., 2013. Profiles of chloride and stable isotopes in pore-water obtained from a $2000 \mathrm{~m}$-deep borehole 506 through the Mesozoic sedimentary series in the eastern Paris Basin. Phys. and Chem. of the 507 Earth, 65, 1-10.

508 Blaesi, H.-R., Peters, T. J., Mazurek, M., 1991. Der Opalinus-Ton des Mt. Terri (Kanton 509 Jura): Lithologie, Mineralogie und physiko-chemische Gesteinsparameter. Nagra Interner 510 Bericht, 90-60. Nagra, Wettingen, Switzerland. $<$ www.nagra.ch $>$

511 Bossart, P., Wermeille, S., 2003. Paleohydrological study of the Mont Terri rock laboratory. 512 In: Heitmann, P., Tripet, J.P. (Eds.), Mont Terri Project-Geology, paleohydrogeoogy and 513 stress field oft he Mont Terri region. Federal Office for Water and Geology Rep. 4, Bern, 514 Switzerland, 45-64. <www.swisstopo.admin.ch>

515 Bossart, P., Thury, M., 2008. Mont Terri Rock Laboratory. Project, Programme 1996 to 2007 516 and Results. Reports of the Swiss Geological Survey, No. 3, 445 pp. Federal Office of 517 Topography (swisstopo), Wabern, Switzerland. <www.mont-terri.ch $>$

518 Bossart, P., Bernier, F., Birkholzer, J., Bruggeman, C., Connolly, P., Dewonck, S., Fukaya, 519 M., Herfort, M., Jensen, M., Matray, J.-M., Mayor, J.C., Moeri, A., Oyama, T., Schuster, K., 520 Shigeta, N., Vietor, T., Wieczorek, K., 2017. Mont Terri rock laboratory, 20 years of 521 research: introduction, site characteristics and overview of experiments. Swiss J. of Geosci., 522 110, doi: $10.1007 / \mathrm{s} 00015-016-0236-1$ 
523 Clauer, N., Techer, I., Nussbaum, C., Laurich, B., 2017. Geochemical signatures of 2524 paleofluids in microstructures from Main Fault of the Opalinus Clay, Mont Terri rock

526 Fierz, T., Rösli, U., 2014. Mont Terri DB Experiment: Installation of a 7-interval multi-packer 527 system into borehole BDB-1. Instrumentation Report. Mont Terri Technical Note, TN 20414528 23. 37 pp. Federal Office of Topography (swisstopo), Wabern, Switzerland. <www.mont529 terri.ch>

530 Gallagher, K., Charvin, K., Nielsen, S., Sambridge, M., Stephensen, J., 2009. Markov chain 531 Monte Carlo (MCMC) sampling methods to determine optimal models, model resolution and 532 model choice for Earth Science problems. Mar. and Pet. Geol., 26, 525-535.

533 Gautschi, A., 2001a. Hydrogeology of a fractured shale (Opalinus Clay): Implications for the 534 deep disposal of radioactive wastes. Hydrogeol. J., 9, 97-107.

535 Gonçalvès, J., Violette, S., Wendling, J., 2004. Analytical and numerical solutions for 536 alternative overpressuring processes: applications of the Callovo-Oxfordian argillite in the 537 Paris Basin, France. J. of Geophy. Res., 109(B2), DOI: 10.1029/2002JB002278

538 Gonçalvès, J., Adler, P.M., Cosenza, P., Pazdniakou, A., de Marsily, G., 2015. Semi539 permeable membrane properties and chemo-mechanical coupling in clay barriers. Nat. and 540 Eng. Clay Barriers, pp. 269-327.

541 Hostettler, B., Reisdorf, A. G., Jaeggi, D., Deplazes, G., Bläsi, H.-R., Morard, A., Feist542 Burkhardt, S., Waltschew, A., Dietze, V., Menkveld-Gfeller, U., 2017. Litho- and 543 biostratigraphy of the Opalinus Clay and bounding formations in the Mont Terri rock 544 laboratory (Switzerland). Swiss J. of Geosci., 110, doi:10.1007/s00015-016-0250-3 
545 Huysmans, M., Dassargues, A., 2005. Review of the use of Péclet numbers to determine the 546 relative importance of advection and diffusion in low permeability environments. Hydrogeol. 547 J., $13(5-6), 895-904$.

548 Jacquier, P., Hainos, D., Robinet, J.C., Herbette, M., Grenut, B., Bouchet, A., Ferry, C., 2013. 549 The influence of mineral variability of Callovo-Oxfordian clay rocks on radionuclide transfer 550 properties. Appl. Clay Sci. 83-84, 129-136.

551 Johns, R. T., Vomvoris, S. G., Löw, S., 1995. Review of hydraulic field tests in the Opalinus 552 Clay of Northern Switzerland. Hydraul. and hydrochem. Charact. of argillaceous rocks. NEA. 19

554 processes in a clay formation in situ experiment: Part B - Results from overcoring and 555 evidence of strong buffering by the rock formation. Appl. Geochem., 26 (6), 954-966.

556 Kuhlemann, J., Rahn, M., 2013. Plio-Pleistocene landscape evolution in Northern Switzerland. 557 Swiss. J. Geosci., 106, 451-467.

558 Mazurek, M., Elie, M., Hurford, A., Leu, W., Gautschi, A., 2002. Burial history of Opalinus 559 Clay. Clays In Nat. And Eng. Barriers For Radioact. Waste Confinement, December 9-12, 560 Reims, France.

561 Mazurek, M., Hurford, A., Leu, W., 2006. Unravelling the multi-stage burial history of the 562 Swiss Molasse Basin: intergration of apatite fission track, vitrinite reflectance and biomarker 563 isomerisation analysis. Basin Res., 18, 27-50.

564 Mazurek, M., Alt-Epping, P., Bath, A., Gimmi, T., Waber, H.N., Buschaert, S., De Cannière, 565 P., De Craen, M., Gautschi, A., Savoye, S., Vinsot, A., Wemaere, I., Wouters, L., 2011. 566 Natural tracer profiles across argillaceous formations. Appl. Geochem., 26, 1035-1064 
567 Mazurek, M., de Haller, A., 2017. Pore-water evolution and solute-transport mechanisms in 568 Opalinus Clay at Mont Terri and Mont Russelin (Canton Jura, Switzerland). Swiss J. of 569 Geosci., 110, doi:10.1007/s00015-016-0249-9.

570 Mills, R.L., and Lobo, V.M.M., 1989. Self-diffusion in Electrolyte Solutions - A Critical 571 Examination of Data Compiled from the Literature. Elsevier.

572 Novakowski, K.S., Van der Kamp, G., 1996. The radial diffusion method 2. A Semianalytical 573 model for the determination of effective diffusion coefficients, porosity and adsorption. Water 574 Resour. Res., 32, No. 6, 1823-1830.

575 Noy, D., Horseman, S., Harrington, J., Bossart, P., Fisch, H., 2004. An Experimental and 576 modelling study of chemico-osmotic effects in the Opalinus Clay of Switzerland. In: 577 Heitzmann, P. ed. (2004) Mont Terri Project - Hydrogeological Synthesis, Osmotic Flow. Rep. 578 of the Fed. Off. for Water and Geol. (FOWG), Geology Series (6), 95-126.

579 Nussbaum, C., Bossart, P., Amann, F., Aubourg, C., 2011. Analysis of tectonic structures and 580 excavation induced fractures in the Opalinus Clay, Mont Terri underground rock laboratory 581 (Switzerland). Swiss J. of Geosci., 104, 187-210.

582 Nussbaum, C., Kloppenburg, A., Caer, T., Bossart, P., 2017. Tectonic evolution of the Mont 583 Terri anticline based on forward modelling. Swiss J. of Geosci., 110, doi:10.1007/s00015$584 \quad 016-0248-\mathrm{x}$

585 Patriarche, D., Michelot, J.L., Ledoux, E., Savoye, S., 2004a. Diffusion as the main process 586 for mass transport in very low water content argillites: 1. Chloride as a natural tracer for mass 587 transport - Diffusion coefficient and concentration measurements in interstitial water. Water 588 Resour. Res., 40, W01516, doi:10.1029/2003WR002700. 
589 Patriarche, D., Michelot, J.L., Ledoux, E., Savoye, S., 2004b. Diffusion as the main process 2590 for mass transport in very low water content argillites: 2. Fluid flow and mass transport modeling. Water Resour. Res., 40, W01517, doi:10.1029/2003WR002700.

Pearson, F. J., Arcos, D., Boisson, J-Y., Fernández, A. M., Gäbler, H.E., Gaucher, E., Gautschi, A., Griffault, L., Hernán, P., Waber, N., 2003. Mont Terri Project - Geochemistry of water in the Opalinus Clay Formation at the Mont Terri Rock Laboratory. Rep. of the Swiss Geol. Survey, No. 5, 143 pp. Federal Office of Topography (swisstopo), Wabern, Switzerland. $<\underline{w w w} \cdot$ mont-terri.ch $>$

Petersen, J.O, Deschamps, P., Gonçalvès, J., Hamelin, B., Michelot, J.L., Guendouz, A., Zouari, K., 2014. Quantifying paleorecharge in the Continental Intercalaire (CI) aquifer by a Monte-Carlo inversion approach of ${ }^{36} \mathrm{Cl} / \mathrm{Cl}$ data. Appl.Geochem, 50, 209-221

Sacchi, E., Michelot J-L., Pitsch, H., Lalieux, P., Aranyossy, J-F., 2001. Extraction of water and solutes from argillaceous rocks for geochemical characterisation: Methods, processes, and current understanding, Hydrogeol. J., 9, 17-33.

Sellin, P., Leupin, O.X., 2014. The use of clay as an engineered barrier in radioactive waste management - a review. Clays and Clay Miner., 61, 477-498.

Soler, J.M., 2001. The effect of coupled transport phenomena in the Opalinus Clay and implications for radionuclide transport. J. of Contam. Hydrol., 53, 63-84

Tarantola, A., 2005. Monte Carlo Methods. Chapter 2 in Inverse Problem Theory and Methods for Model Parameter Estimation. Soc. for Ind. and Appl. Math., 41-56.

Van der Kamp, G., Van Stempvoort, D.R., Wassenaar, L.I., 1996. The radial diffusion method 1. Using intact cores to determine isotopic composition, chemistry, and effective porosities for groundwater in aquitards. Water Resour. Res., 32, No. 6, 1815-1822. 
612 Van der Lee, J., De Windt, L., Lagneau V., Goblet, P., 2003. Module-oriented modeling of 1 ${ }_{3}^{2} 613$ reactive transport with HYTEC. Comput. \& Geosci., 29-3, 265-275.

4

5614 Van Loon, L.R., Soler, J., Müller, W. and Bradbury, M. H., 2004. Anisotropic diffusion in ${ }_{8} 615$ layered Argillaceous Rocks: a case study with Opalinus clay. Environ. Sci. Technol., 38, $616 \quad 5721-5728$.

617 Wersin, P., Waber, H.N., Mazurek, M., Mäder, U.K., Gimmi, T., Rufer, D., Traber, D., 2013. 618 Resolving $\mathrm{Cl}$ and $\mathrm{SO}_{4}$ profiles in a clay-rich rock sequence. Procedia Earth and Planet. Sci, $6197,892-895$

620 Yu, C., Matray, J.M., Gonçalvès, J., Jaeggi, D., Gräsle, W., Wieczorek, K., Vogt, T., Sykes, 621 E., 2017. Comparative study of methods to estimate hydraulic parameters in the hydraulically 622 undisturbed Opalinus Clay (Switzerland). Swiss J. of Geosci., 110, doi: 10.1007/s00015-016$623 \quad 0257-9 h)$ 